\title{
New Actors and Democratic Governance in a Rising Africa
}

\author{
John Rabuogi Ahere* \\ Conciliation Resources, Melbourne, VIC, Australia
}

This paper broadly examines the continued nuancing of the practice of democracy in Africa with a focus on how Africa's democratic governance is increasingly getting influenced by new actors in the international system, who are driving the formation of a new world order that challenges the current unipolar liberal global order. The paper traces the origins and rationale of the democratization project in Africa and uses this as a basis to delve into some issues around which many African countries have increasingly been engaging with new actors. These broad aspects include: Africa's international relations, peace and security; civil liberties as well as investments and trade. This paper contends that some states in Africa are charting middle grounds that increasingly, specifically align with their national/ elite interests, and broadly, is in tune with the consolidating discourse on Africa Rising.

\section{OPEN ACCESS}

Edited by:

Cedric de Coning,

Norwegian Institute of International

Affairs, Norway

Reviewed by:

Lesley-Ann Daniels, Institut Barcelona d'Estudis

Internacionals, Spain

Lipika Kamra,

O.P. Jindal Global University, India

${ }^{*}$ Correspondence:

John Rabuogi Ahere

johnahere@gmail.com

Specialty section: This article was submitted to Peace and Democracy, a section of the journal

Frontiers in Political Science

Received: 18 November 2020

Accepted: 31 December 2020

Published: 29 January 2021

Citation:

Ahere JR (2021) New Actors and

Democratic Governance in a

Rising Africa.

Front. Polit. Sci. 2:630684.

doi: 10.3389/fpos.2020.630684
Keywords: democratic governance, Africa's international relations, Africa Rising, new actors, unipolar liberal global order

\section{INTRODUCTION}

In the last 2 decades, Africa Rising has been a concept used to describe a continent whose states, as a collective, are said to be no longer spectators in global politics and trade. The concept underscores the narrative that governance and economies of African states have continuously been improving to the extent that the continent should be able to deliver on the pre-independence promises of peace and prosperity to their people. But the increased use of that concept in policy and academia has also attracted scrutiny by those who question if indeed Africa is rising. Within the broad discourse of Africa Rising, one of the areas where this scrutiny has happened has been that relating to democratic governance.

Since independence, Africa has had a dalliance with liberal democracy, something that has been referred to as "the democratization project" (Ahere, 2020, p. 38). It has been referred to as a project in the sense that at the time of its introduction and adoption by African states, it was something seen more as a foreign ideology and less as something that was inspired by African people's intrinsic values within their respective socio-cultural contexts. This is because the democratization project in Africa was introduced and continues to be supported by the West, who have had a history of placing immense diplomatic pressure on those countries that were less receptive of the ideology, especially since the fall of the Berlin Wall (Thomson, 2000, pp. 167-168).

Critical scrutinization of the democratization project does not mean that African societies were devoid of participatory forms of democracy before they were colonized. In fact, Ayittey (2005) posits that African societies had participatory forms of democracy, rule of customary law, and accountability with traditional rulers that were not as despotic as typified by colonialists to justify their civilization campaigns in Africa. The political structures that different pre-colonial societies had were based on widely accepted cultural norms whose aims were to ensure that people lived together peacefully and that social order was maintained. The 
contention, therefore, is that in the process decolonization, obtaining independence and in the periods thereafter, the constitutions that most African states wrote were inspired more by the West (e.g. Westminster system) and less by African philosophies such as Ubuntu ${ }^{1}$ among others.

Whereas the West has had the greatest influence on Africa's political dispensations in the last century, the Africa Rising discourse is being held at a time when there is a rise of "new" state-actors (herein referred to as new actors), who are driving the formation of a new world order that challenges the current unipolar liberal global order. Most of these new actors have nuanced and/or customized definitions of what democracy is and are more politically expedient in their relations with African states. These new state-actors include examples such as Brazil, China, India, Indonesia, Japan, Russia, South Africa and Turkey. The "old" and established actors such as China and India might also be considered "new" to the extent that their postures indicate their desires to have a bigger say in global peace and security.

In light of the West's past influence on Africa and the recent rise of new actors, this paper broadly examines the continued nuancing of the practice of democracy in a rising Africa with a focus on how Africa's democratic governance is increasingly getting influenced by new actors in the international system. In addition, the aforementioned examination is done while considering the strategy that African states have adopted in order to continue maintaining relations with the West.

In examining democratic governance, this paper is broadly guided by the definition of Mgbeke (2009, p.1), which questions the extent to which a society is in a condition in which "citizens exercise freedom of speech in a civil society, [participate in] free and fair electoral process [es], and are protected by the rule of law". In unpacking the concept, further examination will be done of some specific issues around which African states' interactions with new actors has impacted on the institutionalization of spaces that enable people's voices to be heard in decision-making processes during the formulation and implementation of policies that affect them.

The new actors that this paper uses to exemplify different assertions include China, Russia, Turkey and South Africa. The rationale behind their selection arises from the fact that their influences are discernible in several arenas in the socioeconomic and political organization of many African states, especially in the affairs and postures of African states that are considered hegemons in their respective geopolitical regions. These actors have gained traction and are challenging the old order in influencing Africa's international relations (at the global and continental levels) as well as in national spaces of African states. These are tackled in that order in the next three (sub)sections.

${ }^{1}$ The Ubuntu philosophy constitutes a core part of most African cultures and is captured in the isiZulu adage Umuntu ngomuntu ngabantu i.e. a person is a person because of other persons (Murove, 2013, p. 37).

\section{New Actors Influence in Africa's Global Politics}

From the 1960s and 1970s when a majority of them obtained independence, African states have over the years increased their participation in international organizations. Most notable is Africa's membership in the United Nations (UN) where it has gained considerable influence in the decisions of the UN General Assembly (Nyangoni, 1985, pp. 26-27). Decision-making in international organizations involves trade-offs between states and this inevitably shapes how some African states supported or fail to support certain initiatives or other states on various issues.

New actors have challenged the unipolar liberal global order in influencing African states' support in determining choice of leadership and decisions of some international organizations. These are normally heavily contested areas between the unipolar liberal global order and new actors. Examples abound. Yang (2019, para. 2) gives the example of the 2007 UN General Assembly (UNGA) when only 10 African countries voted with the United States of America (USA) and her western allies on a resolution on North Korea's human rights record with a majority following China. He adds that 3 decades before, African states tended to shy away from publicly supporting any resolutions that would benefit any of the capitalist or socialist divides as was the case when Africa did not support any side in the Republic of China (Taiwan) vs. the People's Republic of China's tussle to occupy the China seat in the UNGA.

One area of international politics where diplomatic intrigues plays out is on the matter of state recognition. There are some territories that Kolstø (2006, p. 723) refers to as "de facto states", "unrecognized states", "para-states", "pseudostates" and "quasistates". Taiwan is one of these territories and China has vociferously claimed it to be part of its territory; and has gone to great lengths to have it denied diplomatic recognition by many states (Van Fossen, 2007, p. 126). In fact, no African country recognized Taiwan as at $2020^{2}$ and this has been a result of Beijing's diplomatic pressure on African states not to engage in diplomatic relations with Taiwan (Payne and Veney, 2002, p. 108). Russia is also in control of a territory (Chechnya) whose international recognition it is keen to prevent (Tanrisever, 2007, p. 142). Given its overtures to African states as discussed in the next section, it is highly unlikely that most African states could be easily swayed by any international efforts sponsored by the West to seriously look into Russia's human rights violations in Chechnya let alone the issue of state recognition.

It should however be noted that even though the new actors seem united in challenging the unipolar liberal global order in the international system and tend to vote in unison on issues in international organizations (Dijkhuizen and Onderco, 2019, p. 2036), as individual state actors they are competitors for the affection of African states especially in their quests to obtain strategic resources and secure trade pacts (Stolte, 2012, pp. 7-8).

${ }^{2}$ See: https://worldpopulationreview.com/country-rankings/countries-thatrecognize-taiwan. 


\section{New Actors' Influence in African Continental Politics}

The African Union (AU) is the premier organization of African diplomacy and before its formation in 2001, it was preceded by the Organization of African Unity (OAU) which was in existence from 1963. For the most part when the OAU was in existence, global politics was influenced by the East-West divide and this percolated into the discussions and decisions within the organization as different member states were cautious in trying to strike a balance between their national interests and that of the bloc that they identified with in the East-West divide.

The OAU's existence was characterized by the principle of non-interference in the internal affairs of its member states. Because of this principle, Ahere (2020, p. 41) notes that the period from the 1960s to the early 1990s was a "golden age" for African dictators and this could have been enabled in part by what Akuffo (2016, p. 110) notes as the reluctance by the OAU to criticize member states whose leaders subjected their people to authoritarianism and human rights violations. The Soviet Union's and USA's East-West blocs also contributed as they looked the other way as long as the African state under scrutiny was supporting their bloc.

The collapse of the Soviet Union (1988-1991) and ascendance of USA-led dominance with its liberal peacebuilding agenda contributed to a change in thinking within the OAU over the next decade. A manifestation of this was the transformation of the OAU to the AU, which moved away from the stance of nonintervention to that of non-indifference (Williams, 2007, p. 256). Incidentally, this change occurred after significant diplomatic pressures by the West in the 1990s for African states to embrace liberalism in general and (re)introduce multipartyism (Thomson, 2000, pp. 167-168).

Even though the USA-led liberal agenda influenced the structuring of the AU as well as its leaders' perspectives on peace and security, the new actors have been consolidating their influence within the AU by providing resources to make the AU Commission (AUC) and its programs operational. An oftencited case in point is China's $\$ 200$ million donation for the design and construction of the AU Conference Center and Office Complex Building that was opened in Addis Ababa in January 2012 (Abegunrin and Manyeruke, 2019, p. 21). China has also increased its involvement in UN peacekeeping operations in Africa. Kuo (2020, para. 2) notes that China accounted for $15.22 \%$ of global peacekeeping budget in 2019 with two thirds of the budget going to the seven peacekeeping missions in Africa. This gives China significant diplomatic leverage in influencing the designing and implementation of post-crisis recovery roadmaps of the African countries where the peacekeeping missions are mandated. This is especially since the implementation of the aforementioned roadmaps require significant financial resources, which China has, in recent years, been willing to offer in return for lucrative commercial opportunities. Apart from China, it would be useful to briefly highlight the other new actors and obtain an intimation of their influence on the continent's regional integration politics.
Since the mid-2000s, Russia has increased its political, security and economic engagements with Africa. Apart from training African peacekeepers as well as making contributions to the African Peace Fund (Daniel and Shubin, 2017, p. 61), Russia became involved in African peacekeeping and military operations as seen in its involvement in the international anti-piracy task force off the coast of Somalia (Stronski, 2019, para. 8) and its military presence in the Central African Republic (Harding and Burke, 2019, para. 6). Russia has also revved up its diplomatic engagements with African leaders as a collective. The high watermark of these engagements was the 2019 Russia-Africa summit that was held in Sochi from 23 to 24 October; where more than 50 African leaders and 3,000 delegates were present and many lucrative trade pacts were explored. Add these events to the fact that Russia accounted for 39\% of Africa's imported arms between 2013 and 2017 (Signé, 2019, para. 9) - which was more than USA, China or any other world power - the picture that emerges is that in the next decade Russia will be playing a significant role in Africa's continental politics.

South Africa is another actor whose influence in the continent has been steadily increasing, especially since the transformation of the OAU into the AU. Even though it has worthy African state competitors in continental politics, its positioning as a new actor in global politics sets it aside. Apart from significantly contributing to the AU budget ${ }^{3}$, South Africa has actively participated in and funded some African peacekeeping missions. An example is the African Mission in Burundi (AMIB), which at its formation, South Africa took responsibility for approximately $\$ 110$ million of the $\$ 140$ million cost (de Coning, 2017, para. 1). By making these contributions, South Africa has been able to ensure that it has a say in the management of the AU and African peacekeeping missions in which it has significantly invested in. Another notable outlet through which South Africa seeks to project its influence in Africa is through the South African Development Partnership Agency (SADPA). Through SADPA, which is on its latter stages of operationalization, South Africa seeks to engage in development cooperation and has been characterized as an "emerging donor" (Sidiropoulos, 2012, p. 90). Moving into the next decade and at the current trajectory, SADPA is expected to play an immense role in continental discourses on peace, security and development.

Another actor that has been creating waves in Africa is Turkey. Even though its more discernible actions are within national spaces as discussed in New Actors' Influence in National Spaces of this paper, its broader geopolitical motivations are worth mentioning at this point as a precursor to that discussion. Turkey has interests in the Horn of Africa that arise from recent convergence of foreign powers in Djibouti in a bid to have influence in the Red Sea region over issues such as "countering terrorism, piracy and other maritime crime; supporting peace operations; evacuating nationals during

\footnotetext{
${ }^{3}$ South Africa, Egypt, Morocco, Algeria and Nigeria are assessed to contribute $48 \%$ of total assessed contributions to the AU (Pharatlhatlhe and Vanheukelom, 2019, p. 4).
} 
emergencies; and providing humanitarian assistance" (Melvin, 2019, p. 26). Turkey is also involved militarily in North Africa (Libya) with its broader interests being to have a base from which to secure its claims to energy resources located within disputed Mediterranean Ocean maritime boundaries for which it is in competition with Israel, Greece, Cyprus and Egypt (Vrey,, 2020, para. 17).

\section{NEW ACTORS' INFLUENCE IN NATIONAL SPACES}

Whereas new actors have gained traction and are challenging the unipolar liberal global order at the global and continental spaces as discussed in the two previous subsections, it is in the national spaces of African states that perhaps the impacts of the new actors have been felt the most due to ubiquity of bilateral agreements in international relations. The analysis of the postures and actions of the new actors in national spaces can therefore provide an inkling of the extents of their impacts on Africa's democratic governance. There are some specific areas that this section uses to frame the analysis of how new actors influence democratic governance in many African states, i.e. 1) peace and security, 2) civil liberties, and 3) investments and trade. The author arrives at these three areas through thematic concatenation of recent publications that discourse on new actors' activities in African states.

\section{Peace and Security}

At independence, most African states were not in positions to adequately defend themselves against external aggression, especially from their neighbors, most of whom they had and continue to have border disputes with. This is because their militaries and security apparatuses were nascent. As a result, many African leaders got their states into defense agreements with their former Western colonial masters who promised to come to their aid in case they faced internal or external aggression. Examples include Kenya's Jomo Kenyatta's deal with the British when he faced a potential military coup in 1965 (Cullen, 2017, p. 791) and France's defense pacts with its former colonies which saw it station troops in more than 20 African states (Cameron, 2013, p. 60). The Cold War also influenced the defense and security arrangements that African states entered into. Left-leaning administrations or internal rebellions sought military support, equipment and personnel training from the Eastern Bloc while the USA and her allies provided support to capitalist-leaning states and combatants of armed conflicts (Thomson, 2000, pp. 164-165).

The period after the end of the Cold War ushered in some unique challenges. Firstly, as African states succumbed to Western pressure to (re)introduce liberal democracy in the 1990s, the competitive nature of multipartyism (read: elections) became a proximate cause and/or a trigger of many violent conflicts due to the latent issues that many authoritarian regimes had largely been able to muzzle since independence (Cheeseman, 2015, p. 144). Secondly, the global and sophisticated nature terrorism exposed the soft underbellies of many African states which are more often than not caught flat-footed by attacks due to their antiquated security apparatuses. Because of these two reasons among others, African states have needed to become much more proactive and have more agency than before in dealing with peace and security issues. This includes having a wide array of options and alternatives of obtaining the necessary resources and expertize. This is where new actors have become handy.

One area in which new actors have increased their engagements with African states is in military cooperation. This is in the sense of military assistance, training of security personnel and provision of military equipment.

\section{Overt Military Interventions}

In the last decade or so, there have been reports of direct military interventions by the new actors in cooperation with African states. This is of particular interest because prior to this, the new actors had majorly shied away from overt military engagements in Africa, especially when combat was involved. In recent times, some new actors have provided military personnel who have advised and/or provided combat support to some African governments and their allies during armed conflicts. The Libyan conflict is a case in point. Whereas France and other NATO (North Atlantic Treaty Organization) allies have been consistent protagonists since the conflict that led to the fall of Muammar Gaddafi in $2011^{4}$, from $2014^{5}$ Turkey has been playing a significant role. Turkey is the key supporter the of Government of National Accord and the belligerents that are aligned with it in the fight against other forces for the control of Libya (Shay, 2019, p. 3). Incidentally, Russia is on the opposite side of Turkey as it provides mercenaries, military equipment, air support among others to the Libyan National Army and other forces loyal to the Tobruk-based House of Representatives (Kirkpatrick, 2019, para. 3). Other countries where new actors have had recent documented military operations and/or presence include the Central African Republic where Russia (Lister et al., 2019) and South Africa (Ferreira, 2014, p. 10) have been involved, and Somalia where Turkey has a military base from which it conducts anti-piracy missions ostensibly to protect Turkish merchant ships in the Indian Ocean (Antonopoulos et al., 2017, p. 7).

\section{Military Training and Equipment}

If there is an area which has become lucrative for the new actors in Africa, it is in the sale and transfer of military equipment. This has been complemented by offering military training to African soldiers to not only be able to handle the equipment sold or transferred, but also to solidify military relationships with individual states as part of a broader strategy to cultivate political dominance over other powers in the international system. The lucrativeness of sale of military equipment cannot be overstated especially if one considers the number of civil wars

\footnotetext{
${ }^{4}$ This was during the First Libyan Civil War from February 2011 to October 2011. ${ }^{5}$ From 2014, the Second Libyan Civil War broke out among rival factions who wanted to form the legitimate authority in Libya. As of 23 October 2020, there is a permanent ceasefire in force.
} 
that have taken place in Africa in the last 3 decades. In other words, demand for small arms and light weapons in Africa has been high and belligerent groups have always sought avenues from which to obtain them.

Even though Western nations do sell weapons to African states, there have been indications that such sales have broadly been pegged onto peace and security agendas that are generally in sync with the tenets of a liberal world order, e.g., for the concerned African state not to be a global sponsor of terrorism or to adhere to certain human rights standards, etc. The new actors are largely not shackled by the aforementioned need to transact with African states in return for them toeing a specific ideology. However, this does not mean that the new actors' military transactions in Africa are always underboard or questionable. Indeed, through bilateral military agreements that typically respect international law, China, Russia, Turkey and South Africa, all of which sell weapons to African states, normally establish formal channels through which they transact with them (Wezeman, 2011; Young, 2014; Tian, 2018; Signé, 2019). That said, some of the new actors have availed numerous channels (some of which are surreptitious) through which state and non-state actors in Africa can obtain weapons manufactured from their countries or their partners without necessarily having to adhere to legal or moral impediments. For instance, the 2008 hijacking of MV Faina off the coast of Somalia exposed an intricate web of conspiracy. This allegedly involved South Sudan - then under a European Union arms embargo attempting to buy Russian-made weapons carried by a Ukrainian vessel whose owners were concealed by shell corporations but with the sale facilitated by high-ranking Kenyan government officials (Eichstaedt, 2010, p. 137). Whereas such creative avenues of procuring arms have provided some African states with additional options and alternatives from which they could enhance their security apparatus and military strengths, it has also contributed to vicious cycles of armed conflicts and evergrowing organized crime in many states.

\section{Civil Liberties}

An examination of the history of African states reveals that from the time they were colonized in the late 1880 s to the time that the Cold War ended, most of its peoples had gone through close to a century of tyranny, autocracy and authoritarianism (Ahere, 2020, p. 52). The colonial powers used tyranny to subjugate the people in their spheres of influence and upon independence, African leaders, as Fanon (1963, p. 52) notes, manifested the same aggressiveness against their own people because they were afflicted by a malady that Freire (1970, p. 62) may have diagnosed as a type of "oppression" that left the leaders having a strong desire to "want at any cost to resemble [their colonial] oppressors". This is one way of logically explaining the endemic violence in the political cultures of many African states. Regardless of alternative ways that one might use to explain the aforementioned culture of violence, what emerges from a scrutiny of recent mass actions is that civil liberty has in the last 3 decades become an invaluable desire to many ordinary people - at times even more important than economic prosperity. The reason for this is that since independence, there was this over-rehashed mantra among African political elite that economic development took precedence over competitive politics (Ake, 1996, p. 9). This was notoriously used to suppress people's liberties for decades.

The debate of what is important between civil liberties and economic development is one that should not ordinarily arise due to their intertwined nature, but it has been prominent in some African states especially when different social groupings want to justify their approaches to governance and national resource allocation. An example could suffice. The recent rise of strongman and populist leaders in the USA and Europe played a role in providing justifications to the supporters of Kenya's Uhuru Kenyatta when he adopted authoritarian tendencies toward the opposition shortly after his August 2017 election as president was annulled by the Supreme Court a month later. His supporters, mostly from his ethnic group, contended that Kenya needed a "benevolent dictator" like Kenyatta in order to prosper (Madowo, 2018, para. 4). This "civil liberty or economic development" question is a critical one as it has influenced the way the new actors relate with African states, which has by extension impacted on how African peoples are governed.

\section{Human Rights}

Some of the new actors that are focused on in this paper have questionable human rights records in so far as governmentcitizenry relations are concerned. Their modus operandi is one that prioritizes state power over human rights concerns. It therefore becomes curious when the African states that they have heavily invested in increasingly adopt governance styles that relegate human rights concerns of their citizens to the periphery. One way of looking at it would be that they provide inspiration or mentorship to African states' leaders, especially those that are facing challenges from civil society regarding their decisions and decision-making processes. Osondu-Oti (2016, p. 53) gives the example of China which after heavily investing in Sudan's oil sector, reportedly gave "blessings" to Omar Hassan al-Bashir regime's gross violations of citizens' rights during the Darfur conflict. Another way of looking at it is that the new actors rarely admonish or reprimand - at least in public - the malfeasances of the leaders of African states that they closely relate with. This is the opposite of what Western countries do. The latter do not find it difficult to criticize or force the hands of their African allies whenever human rights violations cross some threshold (Mushi, 1995, p. 226). One can therefore be excused if they concluded that should African states' interactions with some of the new actors eclipse that which they have with the West, there is likelihood that there will be increased lip service in African governments' efforts to protect human rights.

\section{Media}

The control of information is at the heart of how some of the new actors maintain their grips on political power in their respective political systems. It is not uncommon to hear that mass media is muzzled in China (Yu, 2009, p. 5), Russia (Hu, 2013, p. 120) or Turkey (Turkey Task Force, 2014, p. 13). Even in South Africa where media outlets have relative freedoms, opposition politicians have often complained about how the national broadcaster, the South African Broadcasting Corporation, has 
been used to solely further the interests of the governing African National Congress (ANC) party at the expense of other parties (Ahere, 2019, p. 10).

Because of the history of authoritarianism in most African states, the media sector is still relatively nascent and mainly in control of the state or companies owned by people close to the ruling elites. Due to cross-ownership of media outlets in some countries as can be seen in Kenya and South Africa (Ahere, 2019, p. 16), social media has become a reliable means of seeking and disseminating information. The efficacy of social media is underscored by the Arab Spring in Egypt where mass protest organizers were reported to have used Facebook to articulate their reform demands and call people to mass action (Alaimo, 2015, p. 2 ). The effectiveness and preference of social media by activists and ordinary persons prompted many African governments to switch off the internet at the very worst or in the least, block access to Uniform Resource Locators (URLs) of social media platforms in their countries. Incidentally, the habit of shutting down the internet or blocking URLs is one that some of the new actors had normalized within their jurisdictions way before its first instance of happening in Africa i.e. in Guinea in 2007 before subsequently becoming rife in other African states. It is therefore not beyond the realm of possibility that some of the new actors mentored or inspired some African leaders to switch off the internet or block social media sites whenever they faced political unrest. CIPESA (2019, p. 5) examined 22 African states that disrupted internet connections in the period 2014-2019 and found that $77 \%$ are authoritarian with the rest being semiauthoritarian regimes. Further interrogation of the same countries reveals deeper relations with and/or investment by China, Russia and Turkey.

\section{Civil Society}

Civil society has played a tremendous role in effecting positive social change in most African states. This was more so during the period from 1970s to the late 1990s when most African states had de facto or de jure one party systems. It is the civil society that played the role that would normally be played by opposition parties. Most governments resorted to clamping down on individuals and organizations associated with civil society. When Cold War ended, Western governments put pressure on African governments to cease clamping down on civil society and went further to fund them in the implementation of initiatives that African politicians of the day felt was their government's preserve. In fact, the first decade after the (re)introduction of multipartyism in the early 1990s witnessed robust growth of civil society organizations (CSOs) in most African countries. As that happened, government-CSOs relations was one filled with antagonism, suspicion and devoid of synergy (Mlambo et al., 2019, p. 7). Even though some of these relationships have improved in some African states in the last decade, it may have a lot to do with the steady funding and protection that CSOs have received from Western governments and less to do with African governments' magnanimity.

Perhaps with the exception of South Africa whose governing ANC party has a history of solid relations with civil society during its struggle against Apartheid, China (Pei, 2008, para. 2), Russia
(Javeline and Lindemann-Komarova, 2010, p. 172) and Turkey (Yabanci, 2019, p. 286) have had governments which in recent years have gone to great lengths to either muzzle or over-regulate CSOs. To this end, these new actors' attitudes toward CSOs has been congruent with that of many authoritarian or semiauthoritarian African states. A case could be made that the new actors and the aforementioned African states rarely reached agreements where the promotion of a vibrant civil society was a priority. It is therefore not a coincidence that in the period that China began to heavily invest in infrastructure projects in some African countries, the latter's governments began to tighten the noose on CSOs by introducing stringent laws to regulate the sector. Examples include Kenya (Churchill, 2013, para. 4), Uganda (Ssejjoba, 2017, para. 1), Sudan (Assal, 2016, p. 4), Ethiopia (Steen-Johnsen, 2017, p. 69) and Zimbabwe (Marwezu, 2007, para. 1).

\section{Investments and Trade}

The new actors have been making growing economic investments in and trading with Africa, especially in the last 2 decades. Since 2013, Turkey's bilateral trade volume with Africa has grown to $\$ 17.5$ billion with total investment estimated at around \$7 billion (Wilson, 2018, para. 2). From 2005 to 2015, trade and investment between Russia and Africa saw a 185\% growth (Gopaldas, 2018, para. 7). Madden (2019, para. 4) notes that from 2014 to 2018, South Africa and China foreign direct investments in African countries were $\$ 10,185$ million and $\$ 72,185$ million respectively. Because of this steady growth of investment and trade and the fact that it challenges the unipolar liberal global order of Western investments, there is the general perception that the new actors are outpacing the West in economic cooperation with African states. Perhaps in a bid to retain the relationships that they have built and enjoyed for so long, Western countries and think tanks have been warning African leaders of unfavorable fine print of the financing agreements that they enter into with some of the new actors (Reality Check team, 2018, para. 20). The warnings by the West, some of which may have some veracity in them, mostly emphasize that some of the new actors' modus operandi would not lead to sustainable development in the African states where financing agreements are undertaken.

\section{Extraction-Focused Investments}

One area of investment in post-independent Africa which has been of focus is the extent to which extraction happens. Africa is as rich in natural resources as it is rich in diversity. There has been contention that the investments that some of the new actors make in Africa have more to do with extracting natural resources and less to do with encouraging equitable benefits between them and African states. China, which has made more visible infrastructure investments than the rest of the new actors has faced a lot of criticism on this issue. There is a school of thoughts that contends that whenever it has invested in infrastructure projects (mostly roads) through loans to African states, these have been concentrated in locations where crucial resources it needs are located (Talbott, 2011, p. 170). This has led to a situation where some regions in some African states continue to remain without basic infrastructure even as some areas with some semblance of 
infrastructure are constantly upgraded. Even when the aforementioned infrastructural investments are done, another contention is that because the contracts are awarded to companies from the new actor states, most of the equipment, materials and skilled labor needed to accomplish such projects are sourced from their countries despite their availability locally. As a result of all these, there have been reports of growing local resentment of foreign workers of the companies implementing such infrastructure projects (Shinn and Eisenman, 2012, p. 8). This in turn has caused tensions between citizens and some African governments that have been forced to go to great lengths to shield the foreign companies and their employees.

\section{Level of Accountability}

The USA-led unipolar liberal global order's transactions with African states are often underpinned by, among other liberal democracy principles, accountability of a government to its citizens. This is manifested in the many reforms initiatives that the West has funded in the governance, justice, law and order sectors in African states. This was more pronounced in the decade that followed the collapse of the Soviet Union. Because these reforms were also crucial elements of bilateral and multilateral financing agreements, some African states came to view them as them as condescending conditions that upset their national sovereignty (Graham, 2019, p. 119).

Some of the new actors have provided African states with the option of not having some of the aforementioned conditions as part of their financing agreements. As a result, some financing agreements are reached without transparency with the subsequent expenditures being susceptible to corruption by African government officials and their business networks. It is therefore not uncommon to come across the concept of tenderpreneurs ${ }^{6}$ in many of the states that have done a lot of single-sourced government-to-government infrastructure projects funded by some of the new actors. These tenderpreneurs have caused egregious corruption to become entrenched in the public sectors, perhaps buoyed by the fact that some of the new actors that their governments deal with do not ask accountability-related questions as long as they get their ends of the deals. Because the involvement of tenderpreneurs, fixers and other middlemen involves hefty kickbacks, the net sufferer is the ordinary tax payer who will fund the government to repay loans taken for projects that were either not delivered at all or grossly over-budgeted. An example is the 2014 deal ( $\$ 3.8$ billion) for the 609-km Standard Gauge Railway in Kenya which was financed jointly by China's Exim Bank (90\%) and the Kenyan government (10\%); it emerged that the cost was inflated by up to three times through insider trading by government officials' networks who anticipated the deal, purchased wayleaves and then inflated the price of the lands (Wang and Wissenbach, 2019, pp. 286-288; Carrai et al., 2020, p. 13). Previously this project was deemed as nonviable by the World Bank.

${ }^{6}$ Bond (2015, p. 203) defines tenderpreneurship as "insider trade deals for state contracts".

\section{Technology Transfers}

The USA-led West and some of the new actors are currently in the middle of intense competition in different technological sectors, most notably over information and communications technology (ICT). This is perhaps most exemplified by the USA's immense efforts to lock out China's ICT giant Huawei from being granted contracts to construct $5 \mathrm{G}$ (the fifthgeneration technology standard for broadband cellular networks) infrastructures in Western countries. In their quests to dominate different sectors in technological advances, Africa is currently an arena through which massive revenues can be generated from selling technological products as the continent currently has relatively smaller penetration, growing economies and robustly rising populations that drive demand. Indeed, some have touted a rising Africa as the next or last Frontier for global growth (Parker, 2012, p. 5).

The issue of technology transfer is one that been at the heart of discourses of sustaining a rising Africa's growth and sustaining its development. The West has long been accused of limiting technology transfers in its relationships with African states in the sense that the focus of technology transfer has been on transfer of the product rather than the skills and capacity to manage the technology throughout its life cycle (Spalding-Fecher and Simmonds, 2005, p. 130). This partially explains why even though some African countries produce a lot of oil, the partnerships that they have entered into with Western companies limits their abilities to learn and use the technologies for their own benefits. This has had the impact of relegating these African states to producers of raw materials who in turn have to import the costlier finished products from the West. To this end, some of the new actors' selling points to African states have been that their development and economic cooperation would lead to technology transfers that would enable the latter to advance and sustain their growths. A look at China may help to underscore the point which can then be related to the other new actors. There is a school of thought that contends that entities from China have been actively engaging in technology transfer through "personnel training, technological cooperation, middle-range technical training and technological spillover" (Li, 2016, p. 185). It adds that this has led to increase in selfemployment as well as growth of entrepreneurship, improved technological environments and promoted the growth of a middle class with better living standards.

On the whole, the new actors have an upper hand to the West in shaping perceptions about technology transfer in Africa. The new actors can package their relationships with Africa as comradely since both sides share a history of being at more or less the same stage of underdevelopment in the 1960s. The new actors can also point out the West's neo-colonization of Africa as one which has ensured that Africa remains subservient to the former - a situation which the new actors can ostensibly help to reverse.

\section{Loans and Their Impacts}

As a continent where many states are underdeveloped but have strategic natural resources, Africa is always looking for money to finance government operations and implement development 
projects that they cannot fund from taxation. These funds have been lent to African states by governments, international organizations and other financial entities. In fact, Africa's external debt in 2019 stood at $\$ 625$ billion (Bizimungu, 2020, para. 9). In relation to this paper, the question being posed is: how much debt is too much debt?

The USA-led unipolar liberal global order of financial entities has for a long time provided loans to African states. That said, the provision of these loans has had a ceiling, determined by among other things, the African states abilities to service the loans without defaulting. This is perhaps because a lot of Western multinational corporations and venture capitalists that have operations in Africa prefer stable economies that are pillared by governments abilities to service their external debts. With their principle of not intervening in how African governments run their affairs, the new actors have brought a new dynamic in Africa's management of its external debt. African states have been particularly warned by the West about accepting attractive loans - especially from China - but whose terms make them strenuous to repay. These warnings have come against the backdrop of allegations that China has, for example, negotiated loans where African states have been obliged to put up ports, airports, among other strategic facilities as collateral in case they defaulted on repayments (Ofstad and Tjønneland, 2019, p. 10). The case of SriLanka which ceded the management of Hambantonta port to China (Kashmeri, 2019, p. 58) has served as a chilling reminder to African activists who have mobilized citizens in some African countries to become increasingly vigilant about ballooning government debts and have organized advocacy forums as well as mass protests to demand accountability in government borrowing and spending.

\section{WHAT WAY FOR AFRICA?}

So far, this paper has delved into some areas and issues around which new actors increasingly influence Africa's democratic governance and did so while comparing and contrasting with the West's influence on the same issues and areas. This paints a picture of an Africa that has to reckon with the crescendo of competing interests of new actors on the one hand and the USAled unipolar liberal global order on the other. At this point it is therefore rational to discuss the question about where a rising Africa could be headed.

In the discourse on Africa Rising, there are those who have discounted the notion that Africa is rising (Fioramonti, 2017, para. 4) and those who have glorified Africa's rise (The Economist, 2011, para. 2) to the extent that one is bound to be forgiven if they concluded that if the continent remained on the same trajectory, it would be where China is at the moment within 50 years. There are also others who in as much as they acknowledge that Africa is rising, warn that the rise is vulnerable to sporadic turbulent spins whose ends might be inevitable crashes for many countries (Ahere, 2020, p. 53). The latter's warning, as alluded to in the introduction section of this paper, is based on the fact that many African states do not seem willing or able to claim agency in crafting their constitutional and policy frameworks based on cultural values and ideologies that, in ordinary African people's minds, influenced pre-colonial societies and should continue to influence the social, political and economic organization of their states. What has happened is that African states have adopted policy frameworks that have more often than not been inspired by external powers. As a result, most of the citizens of these countries (and some policy implementers) neither understand the policy frameworks nor believe in them. This perhaps explains why many African states have very good policies but never seem to have the political will to implement them. To this end, the emergence of new actors necessitates the need to for African states to claim their agency even more as the new actors have broadened the catalog of foreign policy options available for them to adapt but which might distract them from discoursing on what it entails for Africa to continue rising without turbulent spins. In other words, the same way that the West influenced many African states' governance for close to a century, new actors might do the same moving forward. This might be done at the expense of the need for African states to make policies and constitutional frameworks that reflect African people's agency which in turn is informed by their values and aspirations in the specific contexts that they live. The importance of African people's agency in nuancing their practice of democracy in order to make it work for them cannot be overstated. In fact, Ayittey (2010, para. 15) reminds us that liberal democracy, with its focus on individualism ${ }^{7}$, is not compatible with the African ethos and cannot work in Africa the way it works in the West unless it is fundamentally adapted for African societies.

Having said that, there are indications that some African states have used the emergence of the new actors to their advantage. These actors have presented African leaders with more options and alternatives not only in the pursuit of their countries' foreign policies but also in satisfying their citizens' demands for economic development. Some African leaders seemed to have found a workable balance between cooperating with the USA-led unipolar liberal global order on one set of issues while at the same time entering into financing agreements with the China-led new actors to finance projects that they deem too important to go through the immense accountability-related scrutiny of the former. A case in point is Ethiopia which was simultaneously, a key ally of the USA-led old order in the fight against terrorism, while also constructing a massive road and rail network that was heavily financed by China in a 2011 deal (Cheru and Oqubay, 2019, p. 294). A closer look at other African states that have been receiving massive assistance from the new actors reveals that they have also maintained substantial cooperation with the West. This duality in cooperation was rare during the Cold War era when African countries were obliged to pick a side in

\footnotetext{
${ }^{7}$ This contrasts with African philosophies like Ubuntu which guided the worldviews of African peoples for hundreds of years and which, even today, manifests in people's social relations notably in many communities' preference for communalism over individualism and the placement of a high premium on consensus (Ahere, 2020, p. 6).
} 
the East-West supremacy battles - the existence of the NonAligned Movement notwithstanding. The aforementioned duality in cooperation not only indicates a mutation in the global world order but also signals a growing maturity and pragmatism of a rising Africa. At this juncture, one might remember the Solomonic Cold War era statement popularized by Kwame Nkrumah: "we face neither East nor West; we face forward" (Turay, 2013, p. 106). It is a statement that might not have been practicable then but whose time of implementation has come and is inevitable if African is to keep rising.

\section{CONCLUSION}

This paper set out to examine how Africa's democratic governance is influenced by new actors while at the same time maintaining relations with the West. In so doing, it reaffirmed that Africa has been implementing a democratization project whose tenets are inspired more by Western ideologies than by Africans' values. Even though the West has influenced the organization of African political systems and their international relations, new actors have emerged in the international system to challenge the West's unipolar liberal global order.

In their efforts to expand their global influence, new actors have in recent decades been getting into and consolidating relationships with African states on a number of areas of mutual interest. This paper has established that the diplomatic and economic transactions between new actors and African states has generally adversely impacted on the latter's democratic governance. This is because new actors rarely oblige the African states that they cooperate with to uphold certain

\section{REFERENCES}

Abegunrin, O., and Manyeruke, C. (2019). China's power in Africa: a new global order. Cham, Switzerland: Springer Nature Switzerland AG.

Ahere, J. R. (2020). Africa's dalliance with democracy, but whose democracy?," in Africa rising? Navigating the nexus between rhetoric and emerging reality. Editors N. Sempijja and A.K. Molope (Pamplona, Spain: Ediciones Universidad de Navarra, S.A, 37-58.

Ahere, J. R. (2019). Can the media be conflict sensitive? An analysis of Kenya and South Africa. OALib 6 (7), 1-21. doi:10.4236/oalib.1105569

Ake, C. (1996). Democracy and development in Africa. Washington, DC: Brookings Institution.

Akuffo, E. A. (2016). Canadian foreign policy in Africa: regional approaches to peace, security, and development. London, England: Routledge.

Alaimo, K. (2015). How the Facebook Arabic page "we are all khaled said" helped promote the Egyptian revolution. Social Media + Society, 1 (2). 205630511560485. doi:10.1177/2056305115604854

Antonopoulos, P., Villar, O., Cottle, D., and Ahmed, A. (2017). Somalia: Turkey's pivot to Africa in the context of growing inter-imperialist rivalries. J. Comp. Polit. 10 (2), 4-18.

Assal, M. A. M. (2016). Civil society and peace building in Sudan: a critical look. Bergen, Norway: Chr Michelsen Institute. Available https://www.cmi.no/ publications/file/5807-civil-society-and-peace-building-in-sudan.pdf (Accessed 13 November 2020).

Ayittey, G. (2010). Why Western-style democracy is not suitable for Africa [Online]. CNN. Available https://cnn.it/2MpnMH4 (Accessed 3 June 2019).

Ayittey, G. B. N. (2005). Africa unchained: the blueprint for Africa's future. New York, NY: Palgrave Macmillan. governance principles as a condition for further cooperation. To this end, there is a correlation between the new actors' heavy investment in some African states, and those states becoming increasingly authoritarian or lacking in transparency in their governance. Be that as it may, new actors have availed African states with options and alternatives for political and economic cooperation that were limited or unavailable under a dominant unipolar global world order led by the USA.

It is plausible that the huge investments that the new actors have made in Africa have contributed to its growth and has enabled the discourse on Africa Rising to become consolidated. The rising Africa has seemingly learned to chart a middle ground between purporting to practice liberal democracy while engaging with new actors. Even though this duality in cooperation is likely to continue as a new normal, a rising Africa needs to have more agency in formulating and implementing policy frameworks whose main inspirations come from its peoples' cultural values and ideologies - not that which is mainly inspired by the West or new actors. Anything short of that will stall Africa's rise.

\section{AUTHOR CONTRIBUTIONS}

JRA conceived and designed the article, wrote the manuscript, revised the manuscript, reread it, and finally approved the submitted version.

\section{ACKNOWLEDGMENTS}

The author would like to thank the reviewers for their helpful suggestions and comments.

Bizimungu, J. (2020). Report: Africa accumulated largest external debt in 2019. The New Times, Available https://bit.ly/2H6HZzB (Accessed 17 November 2020).

Bond, P. (2015). "Marikana's meaning for crisis management: an instance of South Africa's resource curse," in Global management, local resistances: theoretical discussion and empirical case studies. Editor U. Schuerkens. (New York, NY: Routledge), 192-219.

Cameron, H. (2013). Britain's hidden role in the Rwandan Genocide: the cat's paw. New York, NY: Routledge.

Carrai, M. A., Defraigne, J.-C., and Wouters, J. (2020). "The belt and road initiative and global governance: by way of introduction," in The Belt and Road Initiative and global governance. Editors M. A. Carrai, J.-C. Defraigne, and J. Wouters. (Cheltenham, England: Edward Elgar Publishing), 1-20.

Cheeseman, N. (2015). Democracy in Africa: successes, failures and the struggle for reform. New York, NY: Cambridge University Press.

Cheru, F., and Oqubay, A. (2019). "Catalysing China-Africa ties for Africa's structural transformation: lessons from Ethiopia," in China-Africa and an economic transformation. Editors A. Oqubay and J. Y. Lin. (Oxford, England: Oxford University Press), 282-309.

Churchill, S. (2013). Why NGOs are jittery over public benefits organizations act. Pambazuka News. Available https://www.pambazuka.org/governance/whyngos-are-jittery-over-public-benefits-organizations-act (Accessed 13 November 2020).

CIPESA (2019). Despots and disruptions: five dimensions of internet shutdowns in Africa. Kampala, Uganda: Collaboration on International ICT Policy for East and Southern Africa (CIPESA). Available https://cipesa.org/?wpfb_dl=283 (Accessed 12 November 2020).

Cullen, P. (2017). Operation Binnacle: British plans for military intervention against a 1965 coup in Kenya. Int. Hist. Rev. 39 (5), 791-809. doi:10.1080/ 07075332.2016.1261917 
Daniel, R., and Shubin, V. (2017). The pursuit of strengthened relations in the postCold War era," in Africa and the world: bilateral and multilateral international diplomacy, editors. D. Nagar and C. Mutasa. (Cham, Switzerland: Springer Nature). 51-70. doi:10.1007/978-3-319-62590-4_3

de Coning, C. (2017). Can the AU Finance its own peace operations, and if so, what would the impact be?. [Online]. Addis Ababa and Accra: The African Union and The Kofi Annan International Peacekeeping Training Center. Available at: https:// cedricdeconing.net/2017/03/28/can-the-au-finance-its-own-peace-operations-andif-so-what-would-the-impact-be/ (Accessed 5 November 2020).

Dijkhuizen, F., and Onderco, M. (2019). Sponsorship behaviour of the BRICS in the united nations general assembly. Third World Q. 40 (11), 2035-2051. doi:10. 1080/01436597.2019.1622411

Eichstaedt, P. (2010). Pirate state: inside Somalia's terrorism at sea. Chicago, IL: Lawrence Hill Books.

Fanon, F. (1963). The wretched of the earth. New York, NY: Grove Press.

Ferreira, R. (2014). South Africa's participation in the Central African Republic and Democratic Republic of Congo. Politeia 33 (2), 4-27. doi:10.25159/0256-8845/ 1776

Fioramonti, L. (2017). The "Africa rising story" was based on faulty logic-here's how to fix it. The Conversation. Available at: https://theconversation.com/theafrica-rising-story-was-based-on-faulty-logic-heres-how-to-fix-it-86327 (Accessed 17 November 2020).

Freire, P. (1970). Pedagogy of the oppressed. (New York, NY. Bloomsbury).

Gopaldas, R. (2018). Russia and Africa meet again [Online]. Institute for Security Studies. Available https://issafrica.org/iss-today/russia-and-africa-meet-again (Accessed 16 November 2020).

Graham, M. (2019). Contemporary Africa. London, England: Red Globe Press.

Harding, L., and Burke, J. (2020). Leaked documents reveal Russian effort to exert influence in Africa. Available https://www.theguardian.com/world/2019/jun/ 11/leaked-documents-reveal-russian-effort-to-exert-influence-in-africa (Accessed November 5 2020).

Hu, F.-Y. (2013). Russian news censhorship in the era of anti-terror," in Russia in transition: regional integration, media censorship and culture institutes. Editors F.-Y. Hu. (Newcastle upon Tyne: Cambridge Scholars Publishing), $111-130$.

Javeline, D., and Lindemann-Komarova, S. (2010). A balanced assessment of Russian civil society. J. Int. Aff. 63 (2), 171-188. Available at: https://link. gale.com/apps/doc/A225790777/AONE? $\mathrm{u}=$ dixson\&sid=AONE\&xid=0d99933b.

Kashmeri, S. A. (2019). China's grand strategy: Weaving a new silk road to global primacy. Santa Barbara, CA. ABC-CLIO.

Kirkpatrick, D. D. (2019). Russian snipers, missiles and warplanes try to tilt Libyan War. New York, NY: The New York Times. Available https://www.nytimes. com/2019/11/05/world/middleeast/russia-libya-mercenaries.html (Accessed 10 November 2020).

Kolstø, P. (2006). The sustainability and future of unrecognized quasi-states. J. Peace Res. 43 (6), 723-740. doi:10.1177/0022343306068102

Kuo, S. C. Y. (2020). China's approach to peace in Africa is different. How and why. The Conversation. Available https://theconversation.com/chinas-approach-topeace-in-africa-is-different-how-and-why-129467 (Accessed 5 November 2020).

Li, A. (2016). Technology transfer in China-Africa relation: myth or reality. Transnational Corporations Review 8 (3), 183-195. doi:10.1080/19186444. 2016.1233718

Lister, T., Shukla, S., and Ward, C. (2019). Putin's private army. Atlanta, GA: CNN. Available https://edition.cnn.com/interactive/2019/08/africa/putins-privatearmy-car-intl/ (Accessed 10 November 2020).

Madden, P. (2019). Figure of the week: foreign direct investment in Africa. Washington, DC: The Brookings Institution. Available https://www. brookings.edu/blog/africa-in-focus/2019/10/09/figure-of-the-week-foreign-directinvestment-in-africa/ (Accessed 16 November 2020).

Madowo, L. (2018). Kenya is sliding into a dictatorship. Washington, DC: The Washington Post. Available https://www.washingtonpost.com/news/globalopinions/wp/2018/02/07/kenya-is-sliding-into-a-dictatorship/ (Accessed 11 November 2020).

Marwezu, R. (2007). Zimbabwe: new regulations for NGOs as some suspend aid. ReliefWeb. Available https://reliefweb.int/report/zimbabwe/zimbabwenew-regulations-ngos-some-suspend-aid (Accessed 13 November 2020).
Melvin, N. (2019). The foreign military presence in the Horn of Africa region. Solna, Sweden: Stockholm International Peace Research Institute. Available https://sipri.org/sites/default/files/2019-04/sipribp1904.pdf (Accessed 5 November 2020).

Mgbeke, D. (2009). Public policy implementation in a democratic governance society: a roadmap to empowering citizen participation: an empirical study. Bloomington, IN: AuthorHouse.

Mlambo, V. H., Zubane, S. P., and Mlambo, D. N. (2019). Promoting good governance in Africa: the role of the civil society as a watchdog. J. Publ. Aff. 20 (1), 1-8. doi:10.1002/pa.1989

Murove, M. F. (2013). Ubuntu. Diogenes 59 (3-4), 36-47. doi:10.1177/ 0392192113493737

Mushi, S. S. (1995). Determinants and limitations of aid conditionality: some examples from Nordic-Tanzanian co-operation," in Aid and political conditionality. Editor O. Stokke (New York, NY: Frank Cass), 225-249.

Nyangoni, W. W. (1985). Africa in the United Nations system. London, England. Associated University Press.

Ofstad, A., and Tjønneland, E. (2019). Zambia's looming debt crisis-is China to blame?. Bergen, Norway: Chr Michelsen Institute. Available at: https://open. cmi.no/cmi-xmlui/handle/11250/2600213 (Accessed 17 November 2020).

Osondu-Oti, A. (2016). China and Africa: human rights perspective. Afr. Dev. 41 (1), 49-80. Available at: https://www.jstor.org/stable/10.2307/90001834.

Parker, J. A. (2012). Africa: The next frontier. Chancellor's honors program projects honors thesis. Knoxville, TN: University of Tennessee.

Payne, R. J., and Veney, C. R. (2002). "Taiwan and Africa: Taipei's continuing search for international recognition," in Conceptualizing/re-conceptualizing Africa: The construction of African historical identity,". Editor M. Keita. (Leiden, Netherlands: Brill), 107-120.

Pei, M. (2008). China's repression of civil society will haunt it. London: Financial Times. Available https://www.ft.com/content/46316820-6232-11dd-9ff9000077b07658 (Accessed 13 November 2020).

Pharatlhatlhe, K., and Vanheukelom, J. (2019). Financing the african union: on mindsets and money. Maastricht, Netherlands: ECDPM. Available https:// ecdpm.org/wp-content/uploads/DP240-Financing-the-African-Union-onmindsets-and-money.pdf (Accessed 5 November 2020).

Reality Check Team (2018). Reality check: is China burdening Africa with debt?. London: BBC news. Available https://www.bbc.com/news/world-africa45916060 (Accessed 16 November 2020).

Shay, S. (2019). The escalation of the war in Libya. Alimos, Greece: Research Institute for European and American Studies. Available at: http://rieas.gr/ images/editorial/shaulshaydec19.pdf (Accessed 10 November 2020).

Shinn, D. H., and Eisenman, J. (2012). China and Africa: a century of engagement. Philadelphia, PA: University of Pennsylvania Press.

Sidiropoulos, E. (2012). Emerging 'donor', geopolitical actor: South Africa in the global terrain," in International development policy: aid, emerging economies and global policies. Editor G. Carbonnier. (New York, NY: Palgrave Macmillan), 89-103.

Signé, L. (2020). 2019. Vladimir Putin is resetting Russia’s Africa agenda to counter the US and China. Available at: https://qz.com/africa/1732316/putin-resets-russias-africaagenda-to-counter-china-us/ (Accessed October 26 2020).

Spalding-Fecher, R., and Simmonds, G. (2005). "In Climate change and Africa," in Sustainable energy development and the clean development mechanismAfrican priorities. Editor P. S. Low. (New York, NY: Cambridge University Press), 124-135.

Ssejjoba, E. (2017). Activists condemn new NGO regulations. Kampala, Uganda: New Vision. Available at: https://www.newvision.co.ug/news/1457410/activistscondemn-ngo-regulations (Accessed 13 November 2020).

Steen-Johnsen, T. (2017). State and politics in religious peacebuilding. London, England: Macmillan Publishers Ltd.

Stolte, C. (2020). 2012. Brazil in Africa: just another BRICS country seeking resources?. Available at: https://relooney.com/NS3040/00-CMR_588.pdf (Accessed October 23 2020).

Stronski, P. (2020). 2019. Late to the party: Russia's return to Africa. Available https://carnegieendowment.org/2019/10/16/late-to-party-russia-s-return-to-africapub-80056 (Accessed October 27 2020).

Talbott, J. R. (2011). The 86 biggest lies on Wall street. New york, NY. Seven Stories Press.

Tanrisever, O. F. (2007). Mass media and the internal and external dimensions of the terrorist threats to the stability of the Caucasus," in The media: The terrorists' battlefield. (Amsterdam: IOS Press), 141-151. 
The Economist (2011). The Economist Newspaper Limited. Available. The hopeful continent: Africa rising Available at: https://www.economist.com/leaders/2011/ 12/03/africa-rising\#footnote1 (Accessed 17 November 2020).

Thomson, A. (2000). An introduction to African politics. Oxon, England: Routledge.

Tian, N. (2018). China's arms trade: a rival for global influence?. Lowy Institute. Available at: https://www.lowyinstitute.org/the-interpreter/chinas-arms-traderival-global-influence (Accessed 10 November 2020).

Turay, E. M. (2013). The prophecies of a father. Bloomington, IN: AuthorHouse. Turkey Task Force (2014). Diminishing press freedom in Turkey. Washington, DC: Rethink Institute.

Van Fossen, A. (2007). The struggle for recognition: diplomatic competition between China and Taiwan in Oceania. J. Chin. Polit. Sci. 12 (2), 125-146. doi:10.1007/s11366-007-9008-0

Vreÿ, F. (2020). Turkey in Africa: what a small but growing interest portends. The Conversation. Available at: https://theconversation.com/turkey-inafrica-what-a-small-but-growing-interest-portends-130643 (Accessed 5 November 2020).

Wang, Y., and Wissenbach, U. (2019). Clientelism at work? A case study of Kenyan Standard Gauge Railway project. Econ. Hist. Develop. Reg. 34 (3), 280-299. doi:10.1080/20780389.2019.1678026

Wezeman, P. D. (2011). South African arms supplies to sub-saharan Africa. Solna: stockholm international peace research Institute. Available https://www.sipri.org/ sites/default/files/files/misc/SIPRIBP1101.pdf (Accessed 10 November 2020).

Williams, P. D. (2007). From non-intervention to non-indifference: the origins and development of the African Union's security culture. Afr. Aff. 106 (423), 253-279. doi:10.1093/afraf/adm001
Wilson, G. (2018). Turkey's investment opportunities in Africa. Atlantic Council. Available https://www.atlanticcouncil.org/commentary/event-recap/turkeys-investment-opportunities-in-africa/ (Accessed 16 November 2020).

Yabanci, B. (2019). Turkey's tamed civil society: containment and appropriation under a competitive authoritarian regime. J. Civ. Soc. 15 (4), 285-306. doi:10. 1080/17448689.2019.1668627

Yang, D. (2019). How China's Africa alliance is shifting world order. Rome, Italy: Inter Press Service. Available at: http://www.ipsnews.net/2019/07/chinasafrica-alliance-shifting-world-order/ (Accessed 23 October 2020).

Young, A. (2014). Turkey Is boosting weapons exports with a focus on Africa, here's who benefits. New York, NY: International Business Times. Available at: https://www.ibtimes.com/turkey-boosting-weapons-exports-focus-africaheres-who-benefits-1649300 (Accessed 10 November 2020).

$\mathrm{Yu}, \mathrm{H}$. (2009). Media and cultural transformation in China. New York, NY: Routledge.

Conflict of Interest: The author declares that the research was conducted in the absence of any commercial or financial relationships that could be construed as a potential conflict of interest.

Copyright (C) 2021 Ahere. This is an open-access article distributed under the terms of the Creative Commons Attribution License (CC BY). The use, distribution or reproduction in other forums is permitted, provided the original author(s) and the copyright owner(s) are credited and that the original publication in this journal is cited, in accordance with accepted academic practice. No use, distribution or reproduction is permitted which does not comply with these terms. 